\title{
A música e a dança no teatro de revista carioca* $^{*}$
}

\section{LAURA SILVANA RIBEIRO CASCAES**}

RESUMO: Este artigo tem como objetivo investigar a dança e a música no Teatro de Revista carioca, para analisar as influências do imaginário da modernidade nos números de canto e dança, bem como identificar alguns gêneros musicais incorporados junto à produção da cena revisteira, considerando o bailado do corpo de baile, especialmente as coristas-dançarinas (as chamadas girls) e as rupturas representadas pela modernidade em relação à dança e à música desse período. Pretende-se também destacar a integração de linguagens expressivas e as aproximações e interfaces dialógicas que ocorreram entre a música e a dança no universo revisteiro. Para tal, este artigo se pauta numa abordagem histórica, tendo como procedimento metodológico, estudos existentes sobre este gênero teatral e análise de fotografias. Esta última análise visa observar e identificar aspectos dos gêneros de dança presentes, especialmente as chamadas "danças modernas", e vestígios das identidades sociais das dançarinas.

PALAVRAS-CHAVE: Teatro de Revista; Dança popular; Música Popular; Coristas.

\section{Music and dance in Rio de Janeiro's revue entertainment}

\begin{abstract}
This essay seeks to explore dance within Rio de Janeiro's Revue entertainment theater, in order to analyze the influences of imagination of modernity in ballet dances, as well as to identify some genres, dance techniques and songs incorporated into the production of the Revue scene, taking into consideration the body of dance, especially the chorus-dance girls (the so-called showgirls) and the ruptures represented by modernity in relation to the dance of that period. To this end, the Cultural History method is relied upon as a guide, with existing studies on this theatrical genre serving as methodological derivation. The analysis of photographs, aiming to observe and identify aspects of the genres of dance and songs present therein, in particular the so-called "modern dances", as well as traces of the dancers' social identities.
\end{abstract}

KEYWORDS: Revue Entertainment Theater; Popular Dance; Popular Music; Chorus-dance girls.

\footnotetext{
* Grande parte das considerações deste artigo estão presentes na dissertação de mestrado da referida autora, de 2009.

${ }^{*}$ Laura Silvano Ribeiro Cascaes possui graduação em Pedagogia pela Universidade Federal de Santa Catarina (2002). Em 2009, concluiu o mestrado em Teatro na UDESC. Atua como pedagoga, pesquisadora e bailarina. Participa em projetos educativos, artísticos e culturais. Atualmente é doutoranda do Programa de Pós-Graduação em Teatro da Universidade do Estado de Santa Catarina. E-mail: lauracascaes@gmail.com 
$\mathrm{N}$ o intuito de compreender, de forma breve, o Teatro de Revista carioca e sua história como gênero de teatro musicado na década de 1920, será necessário fazer uma pequena incursão sobre sua chegada ao Rio de Janeiro como Revista de Ano, para, posteriormente, melhor explicitar as transformações que ocorreram no panorama revisteiro na segunda década do século XX.

\section{O Teatro de Revista e sua história no Brasil como gênero do teatro musicado}

Veneziano (1996) pontua que o Teatro de Revista surgiu no século XVIII, a partir da união da Commedia dell'Arte com a Comédie Française, nos teatros de feira de Paris. A autora situa o Teatro de Revista numa região fronteiriça entre o Teatro $\mathrm{Mu}$ sical $^{1}$ e o Teatro Popular:

Nem a Revolução Francesa deteve a escalada do gênero criado, que evoluía como uma mistura de vaudeville e opereta para o que se denominaria revue de fin d'année. Da França a revista seguiu para outros países e Portugal foi um dos primeiros a adotá-la, em 1851 (VENEZIANO, 1991, p.23).

Segundo Saliba (2002), o fato é que o Teatro de Revista, até se estabelecer como um gênero de teatro musicado específico, irmanou-se com outros sistemas dramatúrgicos afins, especialmente o vaudeville 2 e a opereta ${ }^{3}$.

Assim sendo, o Teatro de Revista aportou no Brasil, via Portugal e, lentamente, foi conquistando público e obtendo aceitação popular, tanto que no período de 1920 a 1940 tornou-se o gênero dominante nos palcos brasileiros.

\footnotetext{
1 Segundo Veneziano (1996), a categoria de teatro musical possui vários gêneros afins: burleta, vaudeville, féerie, opereta, cabaret, café-concerto, music hall.

${ }^{2}$ De acordo com Veneziano (1996), em relação ao vaudeville: "O sentido francês do termo, aplica-se às peças de intriga complicada, baseada em coincidências de caráter extraordinário [...] No quiprocó e no equívoco baseia-se o vaudeville [...]" (VENEZIANO, 1996, p.24). Assim, este gênero teatral, diferentemente do Teatro de Revista, não tinha como objetivo a revisão de acontecimentos.

${ }^{3}$ As operetas, segundo Veneziano (1996), possuem grande familiaridade com a Revista: "[...] Misto de comédia e melodrama, o qual era sempre levado na brincadeira, entremeada de números musicais (que iam da valsa ao can-can, evidentemente) a opereta referia-se também a assuntos do cotidiano imediato. Sob uma aparente aura sentimental (nesse sentido é evidente a diferença com a revista), ela poderia ser também ferina, crítica, mordaz. Mas o amor era o seu tema central e o allegro-vivace seu andamento [...] aportou em triunfo no Rio de Janeiro, antes mesmo da Revista." (Veneziano,1996, p.26). Segundo a referida autora, a opereta estreou na capital federal, em 1846.
}

CASCAES, Laura Silvana Ribeiro. A música e a dança no teatro de revista carioca. Música Popular em Revista, Campinas, ano 1, v. 2, p. 86-103, jan.-jun. 2013. 
Era um gênero teatral que problematizava o cotidiano, expondo as questões sociais e políticas de forma caricata e paródica, com personagens-tipo, números de dança e canto, esquetes e apoteose como desfecho. Com todo o elenco no palco, tinha o intuito de encantar e alegrar seu único e dileto alvo: o público. Saliba (2002) pontua que nos últimos decênios do império, o gênero ainda era difuso, apoiando-se e desmembrando-se das operetas, dos vaudevilles e das produções teatrais europeias de caráter cômico, de entretenimento e diversão.

Em 1859 ocorreu a primeira apresentação revisteira brasileira em terras brasilis com o texto As Surpresas do Senhor José Piedade, de Figueiredo Novaes, e também a inauguração da Alcazar Lyrique ${ }^{4}$, uma casa de espetáculos muito importante para a rede de sociabilidades na cidade do Rio de Janeiro, já que "[...] parece ter apontado ao teatro nacional um rumo a seguir, despertando na sociedade carioca o gosto pelo mundo colorido e sensual do teatro ligeiro" (VENEZIANO, 1991, p.27).

O Teatro de Revista foi diferenciando-se dos outros sistemas dramatúrgicos e firmando sua estrutura e convenções enquanto gênero de teatro musicado específico, através das linhas mestras dadas pela dramaturgia, desenhadas por alguns autores, que se destacavam nesse período.

Tem início o deslanchar do riso revisteiro nacional com Artur Azevedo, depois de ter sido um dos autores da Revista O Rio de Janeiro de 1877, que não teve grande projeção. Em 1882, ele se destaca no âmbito revisteiro, após retornar de uma viagem à Europa, onde teve oportunidade de conhecer as revistas europeias das cidades de Madrid, Paris e Lisboa (MENCARELLI, 1999). Após retornar para o Rio de Janeiro, juntou-se a Moreira Sampaio e formou uma ilustre parceria bem sucedida de escritores, que deflagraram o processo de aceitação da revista no Brasil, a partir da peça O Mandarim, de 1883. Soma-se a esse gênio do riso, uma geração de escritores que deram uma "nova expressão de sua inteligência que lhes permitiu ver, ironizar e sondar a alma brasileira, através de momentos marcantes desse teatro leve e tão importante no desenvolvimento da cena nacional" (VENEZIANO, 1991, p.12).

\footnotetext{
${ }^{4}$ Alcazar Lyrique: "[...] o templo da opereta no Rio de Janeiro, que trouxe as mais belas e sedutoras atrizes francesas para a boemia noturna. [...] Misto de café-cantante e vaudeville, este teatro que ocupava três prédios, tornou-se a mais famosa e ruidosa casa de espetáculos do Rio de Janeiro, tendo sido fechada somente em 1886 e aberto caminho para as paródias e revistas, conhecidas como estavam as tendências da plateia" (VENEZIANO, 1991, p. 27).

CASCAES, Laura Silvana Ribeiro. A música e a dança no teatro de revista carioca. Música Popular em Revista, Campinas, ano 1, v. 2, p. 86-103, jan.-jun. 2013.
} 
O Teatro de Revista, num primeiro momento, foi chamado de Revista de Ano, porque, através de sua dramaturgia e convenções, fazia uma revisão dos acontecimentos anuais mais significativos. Segundo Mencarelli:

Num gênero como as revistas de ano, por exemplo, a obra não tem uma unidade temática ou uma idéia central a apresentar. $\mathrm{O}$ autor faz algo semelhante a um trabalho jornalístico através do teatro, registrando os fatos mais relevantes ou pitorescos que ocuparam a atenção da cidade durante o ano que passou. O objetivo do autor, não é, portanto, defender uma idéia, uma moral, ou desenvolver algum tema central: a regra aqui é conseguir a empatia do público através daquilo que mereceria um comentário crítico e bem-humorado por ter marcado o cotidiano da cidade (MENCARELLI, 1999, p. 34, 35).

Esse gênero teatral estreia no Brasil em 1859, período em que se esboça gradativamente no país o desejo de implementar a República e de superar tudo o que remetesse ao Brasil colônia. Esse desejo ficou cada vez mais forte nas primeiras décadas do século XX, período marcado pela ânsia do progresso, de superação do "atraso" do país; pela intenção de abandono da condição de país rural e pobre, gerando tensões e embates entre campo $\mathrm{x}$ cidade, agrário-rural $\mathrm{x}$ urbano, provinciano $\mathrm{x}$ cosmopolita, antiquado x moderno, oligárquico x liberal. Estas mudanças e desejos advindos com a modernização da cidade do Rio de Janeiro foram projetados diretamente no Teatro de Revista, que dialogava com a revisão histórica dos principais acontecimentos citadinos. Sua estrutura e convenções dramatúrgicas paulatinamente sofreram modificações pelo diálogo com os repertórios da modernidade.

A Revista O Mandarim, de Artur Azevedo e Moreira Sampaio, de 1883, deflagrou o processo de implantação do gênero no país. Esse texto seguia a fórmula da Revista de Ano que, em seu prólogo, apresentava a personagem o Mandarim anunciando um compère ${ }^{5}$ de condição chinesa. A atualidade principal do enredo estava centrada na imigração chinesa, que interessava aos barões de café enquanto mão-deobra nas fazendas para substituir a mão-de-obra escrava, diante da ameaça do advento da abolição (VENEZIANO, 1996). Os três atos do texto foram entremeados de situações dramáticas e cômicas. A apoteose final tinha conteúdo patriótico e ufanista ao som do hino nacional.

\footnotetext{
${ }^{5}$ Compère - Muitas vezes acompanhado da commère - o compadre e a comadre - desempenhavam o papel de articuladores do enredo, inter-relacionando os quadros, as cenas e respeitando um fio condutor (Veneziano, 1991). 
Na Revista de Ano, seguindo o exemplo de O Mandarim, de 1883, era estruturada em um prólogo e três atos, divididos em 11 quadros. Os números de canto não eram preponderantes; as cenas dançadas, embora em número reduzido, já se faziam presentes. Na Cena VI, do Ato I, o bailado surgia no final do quadro, conforme marcação do texto, onde os artistas "dançam uns com os outros no fim do canto". Na cena X, do Ato II, quadro VII, destaca-se o número de dança na qual apareciam:

brasileiros dançando um lundu; - Segunda entrada - Portugueses dançando a Cana Verde; Terceira entrada - Bailarina Brasileira; - Quarta entrada Ingleses que aparecem ao som de God Save e dançam o solo inglês; Quinta entrada - Franceses, Grande Cancã ${ }^{6}$.

Deste modo, uma série de ritmos e danças marcavam os bailados revisteiros. Do lundu ao cancã, a Revista de Ano foi abrindo gradativamente espaço para a dança e para a música despontarem soberanas nos espetáculos de Revista na década de 1920.

As operetas foram responsáveis por difundir o cancã, e no Alcazar Lyrique alcançaram muito sucesso. Mencarelli (1999) nos informa que: “O grande escritor e libretista francês Jacques Offenbach tinha elevado a opereta a uma estatura de dignidade entre os outros gêneros dramáticos, tinha extraído de seu ritmo próprio, o cancan, o melhor de sua fórmula" (MENCARELLI, 1999, p. 82). O referido autor menciona o questionamento de Artur Azevedo a respeito da música nos espetáculos na Revista de Ano: “[...] o maxixe, que era o ritmo popular brasileiro de sucesso naquele momento, e que estava presente em praticamente todos os espetáculos, não poderia ser tão adequado e nobre para a revista quanto o cancan o era para a opereta?

O cancã também se fez presente na cena revisteira, mas estava estritamente vinculado à opereta:

A opereta caracteriza-se por ser uma forma de ópera popular, mas que, diferentemente desta, não teve origem nobre, mas a partir dos espetáculos de feira. Conta uma história leve e bem humorada através de canções. Surgida na França, em meados do século passado, teve grande florescimento na época, principalmente entre as duas grandes exposições de Paris, de 1855 a 1867, quando seu representante mais famoso era Jacques Offenbach. Depois, teve grande

\footnotetext{
${ }^{6}$ Informações do texto O Mandarim, de Artur Azevedo, obtidas na obra: Teatro de Artur Azevedo. Tomo II. R.J.: INACEN,1985, p.233 e 258.
} 
desenvolvimento na Viena de final do século XIX. Offenbach, em pouco tempo, triunfaria também no Rio de Janeiro (MENCARELLI, 1999, p.56).

Os gêneros de danças presentes nas Revistas de Ano foram muito variados. Nesse percurso, até a década de 1920, havia, muito improviso na sua estrutura interna, o que proporcionava uma gama muito grande de experimentações. Eram espaços criativos, atuando como: “[...] laboratórios de experimentações cênicas, musicais e, principalmente coreográficas" (PEREIRA, 2003, p.162).

Segundo Caldeira (1999), os movimentos das danças no Teatro de Revista revelavam o mistério arquetípico, que liga o corpo à terra, remetendo às danças primitivas e sociais, como também à força simbólica dos movimentos que exaltavam o caráter dionisíaco, presentes nas movimentações dos bailados.

A dança do maxixe estava inserida nesse contexto. Este gênero dançado consistia no requebrado e rebolado com os quadris, ampliando o espaço da proximidade entre os pares, através de um bailado que envolvia a parceria entre homem e mulher. No primeiro decênio do século $X X$, o maxixe teve um destaque maior nos bailados revisteiros.

Jota Efegê (1974) evidencia a prática coreográfica do maxixe, descrita pelo português João Chagas (1897):

\footnotetext{
Os pares enlaçam-se pelas pernas e pelos braços, apóiam-se pela testa num quanto possível gracioso movimento de marrar e, assim unidos, dão a um tempo três passos para diante e três para trás, com lentidão.

Súbito, circunvolunteiam, guardando sempre o mesmo abraço e, nesse rápido movimento, dobram os corpos para frente e para trás, tanto quanto o permite a solidez dos seus rins; tornam a volutir com rapidez e força, tornam a dobrar-se, e, sempre lentamente, três passos à frente, três passos atrás, vão avançando e retrocedendo, como a quererem possuir-se.

Dança-se com doçura e dança-se com frenesi (EFEGÊ, 1974, p.51).
}

A coreografia do maxixe revelava, então, requebros um tanto lascivos e, devido a isso, ele foi impregnado de polêmicas e permaneceu escandalizando os grupos conservadores da sociedade carioca por muito tempo. Esses bailados traduziam o berço desta dança acalentada em sua matriz pelos batuques africanos.

Na década de 1920, segundo Veneziano (1991; 1996), encontra-se a fórmula revisteira brasileira. Vários foram os motivos destas transformações: a morte dos escritores Moreira Sampaio, em 1901, e Artur Azevedo, em 1908; a afirmação de 
novos autores nessa década; as mudanças advindas com a modernidade que atingiram diretamente a cidade do Rio de Janeiro; a Primeira Guerra que provocou um desenvolvimento da produção teatral nacional, bem como a visita de companhias estrangeiras, a Ba-ta-clan e Velasco. O advento do cinema, das jazz-bands, do rádio, do carnaval, da cultura americana também foram alguns motivos destas mudanças, entre outros. A Revista de Ano é superada, aproximadamente, no final do primeiro decênio do século XX.

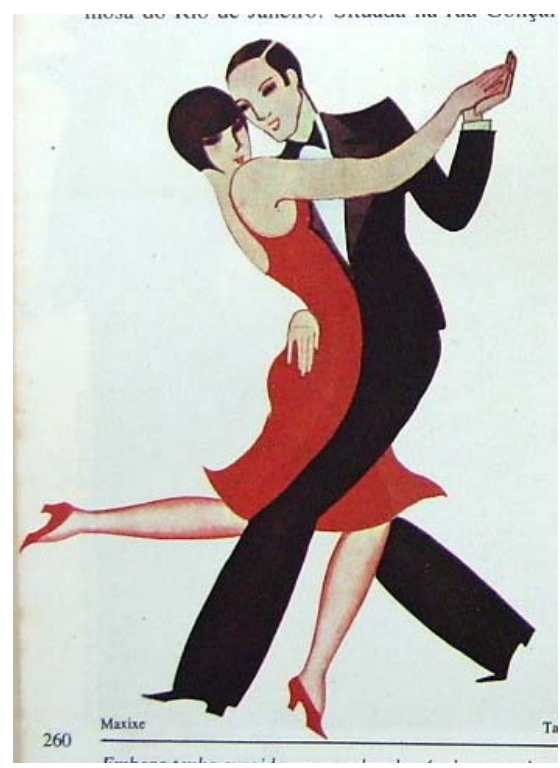

Imagem 1 - Maxixe. Fonte: Nosso Século: 1910-1930. São Paulo: Abril Cultural, 1980: p. 260.

A partir desse período, especificamente nas décadas de 1920 e 1930, a Revista de feições carnavalescas popularizava-se, agradando ao público. Transformavam cada vez mais as feições ortodoxas, tradicionais e luso-francesas numa crescente irradiação do carnaval nos quadros convencionais, demarcando-o como aspecto formal - uma convenção dramatúrgica- que tornava a produção revisteira brasileira. Esta vinculação da revista com o Carnaval estendeu-se para além do período précarnavalesco, com as músicas, as principais marchinhas lançadas pelas revistas e o ritmo de Carnaval (VENEZIANO, 1996).

No entanto, o fluxo das apresentações de outras Revistas com outras temáticas eram incessantes durante o ano, popularizando também outras canções de sucesso que não se restringiam somente ao samba.

Na década de 1920, firmou-se outra estrutura revisteira caracterizada por ter um fio condutor muito frágil, ligado não mais aos acontecimentos anuais, mas aos 
acontecimentos circunstanciais e de atualidade, com uma estrutura básica que reduziu os antigos três atos para apenas dois. A estrutura constituía-se de um prólogo, dois atos e duas apoteoses (VENEZIANO, 1991).

Segundo Veneziano (1991), a Revista consolidou a estrutura clássica, sem enredo em termos de fio condutor do espetáculo, com quadros de canto e dança equiparados e no mesmo patamar dos quadros de comédia e do texto declamado. Trouxe também outra grande inovação: a partir de 1925, as transformações gradativas ocorridas na revista "colocam o corpo feminino, emoldurado por coreografias adequadas e músicas contagiantes, como real centro de interesse" (VENEZIANO, 1996, p. 86/87).

A música ocupou lugar privilegiado na Revista nessa época, no mesmo patamar do texto, constituindo-se em elemento central, e o apuro nas melodias dividia o espaço com os bailados, também muito relevantes nas Revistas. (VENEZIANO, 1991).

\section{Caminho de flores: a Revista na década de 1920}

A roupagem do teatro de revista da década de 1920 inaugura uma proposição estética mais desejosa de romper com o passado, com os preceitos luso-franceses. Para tal, as influências estrangeiras eram "antropofagicamente" deglutidas e adaptadas à realidade brasileira. Com este processo de "antropofagia", através do olhar dirigido ao que é nosso, solidifica-se uma nova estética na revista, conquistando o dileto público, pois atendia às novas expectativas da população, proclamando a identidade cultural e o imaginário popular.

Segundo Herschmann e Pereira, a ideia de antropofagia apostava no

vigor crítico da "força nativa" para inverter o sentido da colonização e abrir caminho para a resistência cultural - se explicita como tentativa de se buscar uma saída para intrincada questão da 'identidade cultural/nacional' de um país colonizado que procurava se afirmar intelectualmente diante da metrópole e de si mesmo. (HERSCHMANN; PEREIRA, 1994, p. 36)

Desta forma, a cena revisteira firmou uma nova linguagem, que incorporava e se apropriava de tendências estrangeiras, de modo a ressignificá-las e adaptá- 
las à realidade do país, com as novas práticas culturais e de sociabilidades geradas pela modernidade no Rio de Janeiro nos anos 1920, já considerada como uma cidade cosmopolita.

O modo de apropriar-se das influências estrangeiras nas danças se pautava em processos genuínos de devorar influências, "antropofagicamente”, mediante à complexidade cultural envolvida na sua construção e nos seus deslocamentos.

O Teatro de Revista tornou-se um espaço de divertimento e entretenimento da população urbana:

Conquistada a simpatia popular, a revista se afirmou, solidificando uma posição como meio de diversão nas cidades, incorporando influências e se aperfeiçoando tecnicamente. Integrou-se ao mundo civilizado sem esquecer de destacar as singularidades brasileiras ao beber, constantemente, na fonte da cultura popular. Ser moderno na ebulição cultural da década de 1920, era ser brasileiro (ANTUNES, 1996, p.26).

A cena revisteira valorizava os aspectos da brasilidade, representadas pelos "brasileirismos", palavras utilizadas no texto, um jeito de falar "à brasileira", abandonando o sotaque português. A música consolidava o elemento fundacional da brasilidade. Velloso (2005, p.169) pontua que a música “[...] se apresenta como poderoso canal de comunicação lingüística, acionando elementos de ordem afetivo-intelectual, fortemente mobilizadores no tocante as idéias de pertencimento e de identidade".

A presença de tipos fixos também amalgamava elementos folclóricos e regionais. Apostando num olhar crítico para as atualidades, revisava-as criticamente, de forma a expressar-se com humor e irreverência, devolvendo, antropofagicamente, por meio de quadros cômicos aquilo que, muitas vezes, vinha de fora: uma apropriação cômica, um jeito de incorporar os estrangeirismos.

A Revista abordava, de modo antropofágico, os contrastes de um país, que se desejava moderno e veloz, o qual buscava superar o coronelismo, o clientelismo e substituir por um Brasil moderno do qual o Teatro de Revista era um paradigma bem atual.

O desenvolvimento da técnica do fazer revisteiro, de acordo com Antunes (1996), permitiu o desenvolvimento de uma arte de massa, consolidando-se, assim, 
um mercado para o entretenimento popular, com empresários que investiam em montagens grandiosas e dispendiosas (PAIVA, 1991).

\section{Coristas na cena revisteira}

Os números de canto e dança, como eram concebidos na década de 1920, foram se estabelecendo na estrutura dramatúrgica revisteira, como fruto de um longo processo de mudanças. Algumas Revistas de Ano já sugerem, sutilmente em seus textos, os momentos dos números de dança, como em Cocota, de 1884, de Artur Azevedo, em que aparece no texto a presença de um coro e bailados, mas, para a acepção do termo de coristas como é entendido nessa época, existe aí uma grande distância.

Durante a década de 1920, a designação da categoria de coristas foi mudada. Segundo Ruiz (1984, p. 62):

[...] as coristas 7 , reminiscências dos tempos da ópera, da opereta, da zarzuela, da burleta - em que elas eram mais cantoras que bailarinas - passaram a ser girls, a princípio distinguidas das outras por serem "coristas-bailarinas". E era aí que estava o segredo maior. As meninas, as garotas, tinham agora que dançar mais e cantar menos).

O processo de formação do grupo de coristas, desde o final do século XIX, merece ser melhor estudado. Esta é uma história ainda por ser escrita, diz Bevilacqua (2001, p.74) sobre o processo de formação do grupo de coristas na revista brasileira. José Ramos Tinhorão (1972) pontua que a apresentação da revista La Gran Via, no Rio de Janeiro, por uma companhia espanhola, em 1887, desencadeou uma profunda transformação no Teatro de Revista brasileiro:

Quando em 1887, porém, uma companhia espanhola apresenta na revista La Gran Via a novidade coreográfica da evolução das coristas no palco, ao som da música, o espírito do espetáculo muda radicalmente, e os monólogos e cançonetas dos solistas começam a alternar com números musicais em que as coristas se movimentam cantando, o que desde logo leva a descoberta do carnaval como tema de revista (TINHORÃO, 1972, p.15).

\footnotetext{
${ }^{7}$ Opto por continuar usando a palavra corista no decorrer do texto, ao invés de girl, termo utilizado na década de 20, para firmar a referência do corpo de baile numa palavra do português. Mesmo com o foco de pesquisa nessa década, alerto que esta designação do termo se refere ao sentido de girl, quando o coro dança mais e canta menos. 
A passagem da companhia espanhola produziu um impacto na evolução coreográfica das coristas, ao intercalá-las com os monólogos e cançonetas, valorizando a visualidade e as músicas.

Em seguida, ainda em 1887, Oscar Pederneiras faz também a sua paródia do texto espanhol e a denomina de O Boulevard da Imprensa. Nessa Revista, o papel cênico das coristas foi valorizado devido ao fato de representarem as três maiores sociedades carnavalescas cariocas (BEVILAQUA, 2001).

Cada vez mais os momentos musicais adquirem espaços na escrita revisteira até que, na década de 1920, passaram a reinar os bailados, os efeitos coreográficos, cenográficos, as vedetes, a música, ou seja, o visual e o sonoro ganharam projeção dentro do espetáculo musical revisteiro.

Com a proclamação da República, em 1889, o Brasil republicano organizou-se sedimentado na República dos Conselheiros, que se articulava em torno da oligarquia cafeeira que, segundo Sevcenko (2003, p.102), esforçava-se para "forjar um Estado Nação Moderno no país. Para tal, fundamentava-se na 'europeização das consciências'",

Este processo de "europeização das consciências" atingiu diretamente o Teatro de Revista, na maneira de produzi-lo. Sua escritura, sua encenação, seus bailados, até quase o final da década de 1910, foram feitos com base nos preceitos luso-franceses, época em que começa a despontar uma linguagem revisteira brasileira.

O trabalho do escritor Luiz Peixoto foi fundamental para consolidação destas mudanças, já que a sua viagem para a França, na década de 1920, permitiu a assimilação de muitas novidades que foram incorporadas no seu trabalho como revistógrafo como a valorização da beleza e visualidade e a ênfase na velocidade dos quadros (VENEZIANO, 1996). O corpo de baile de coristas, através de coreografias, marcações e plasticidade, busca atingir a homogeneidade dos movimentos.

As mudanças que ocorreram nessa época foram o resultado de um conjunto de repertórios da modernidade. Nessa década, o Brasil intensifica a inclinação do olhar para os Estados Unidos da América, e essas transformações se fazem sentir, principalmente, através dos cinematógrafos, da música e das danças. Os ritmos 
norte-americanos, representados pelo foxtrote e pelos ragtimes se destacam na cena revisteira (VENEZIANO, 1991). Difundem-se, também, o charleston, o shimmies, o onestep, entre outros.

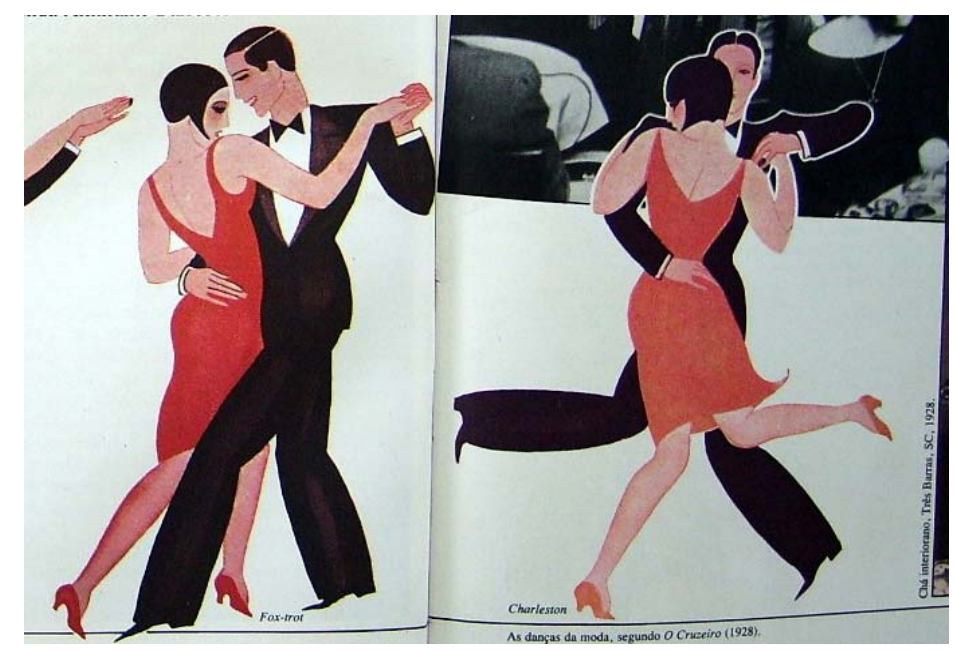

Imagem 2 e 3, respectivamente - Foxtrot e Charleston. Fonte: Nosso Século: 1910-1930. São Paulo: Abril Cultural, 1980: p. 260 e 261.

Segundo Paiva (1991), nesse contexto cultural, também foram importantes a visita de duas companhias estrangeiras de Teatro de Revista, a Ba-ta-clan (da França) e a Velasco (da Espanha), com suas turnês no Brasil, as quais influenciaram sobremaneira o modo de produção da cena carioca no Teatro Musicado, representando rupturas importantes no Teatro de Revista Brasileiro como um todo.

Após 1922, data que demarca a primeira visita da companhia Ba-ta-clan ao Brasil, progressivamente os quadros de fantasia passaram a ter um cuidado mais apurado. Muitos bailados do nosso Teatro de Revista foram coreografados, o corpo disciplinado com movimentos justos, no sentido de seguir orientações coreográficas, seguidas de forma disciplinada, buscando, desse modo, criar movimentos mais homogêneos. (PAIVA, 1991). Também se torna importante atingir a precisão de acompanhar a música e movimentar-se igual ao conjunto, ocorrendo uma grande mudança na estrutura das coreografias, que começaram a ser elaboradas em sintonia com as influências da modernidade coreográfica.

Em relação ao trânsito de informações que permeavam o corpo de baile revisteiro no Teatro de Revista, Pereira (2003, p. 172-3) pontua que: questões sobre o corpo nacional, através de seus tipos característicos, de suas mú- 
sicas e de suas danças, é claro que havia ali mais do que uma convivência, mas uma interpenetração de informações.

Desse modo, o corpo comunicava narrativas simbólicas e significados culturais presentes na sociedade, tal como a busca pela brasilidade, num cruzamento de informações presentificadas nele mesmo, reelaboradas e resignificadas, perpassando desde estilos e técnicas de dança incorporadas junto à produção da cena dos números de canto e dança, até as apropriações de elementos da construção de identidades sociais.

\section{Entre a música e a dança}

Esse gênero de teatro musicado, por sua vez, popularizou canções brasileiras hoje imortalizadas, que contaram com a participação de músicos importantes da música popular, como Donga, Pixinguinha, Sinhô, Henrique Vogeler, Lamartine Babo, entre outros; muitos destes ligados também a uma multiplicidade de gêneros musicais, que tiveram alguns de seus sucessos lançados na cena revisteira. Por sua vez, o caminho também foi de mão dupla, já que o Teatro de Revista projetava e difundia as músicas populares brasileiras para as massas, ou mesmo aproveitava os sucessos de algumas dessas canções para garantir o êxito da peça revisteira colocada em cartaz. Nesta perspectiva, as danças dialogavam com o ritmo das músicas. Ocorriam, assim, interfaces dialógicas entre as linguagens expressivas.

Parece que alguns músicos também foram estabelecendo diálogos com a dança, como é o caso de Lamartine Babo que, curiosamente, segundo Tinhorão (1972) também deu aulas de dança em 1928 nos clubes Tuna Comercial e Ginástico Português, ensinando as danças da moda e valsas.

Os músicos também estabeleciam táticas para melhor repassar os procedimentos musicais para o conjunto revisteiro. $\mathrm{O}$ autor nos revela os encaminhamentos de Henrique Vogeler. De espírito calmo e desprendido, Vogeler, na cena revisteira, esmerou-se junto ao corpo de baile, encontrando mecanismos para ensinar o compasso da música às coristas: 
[...] Henrique Vogeler descobria formas divertidas de ensinar o compasso certo das músicas. Com fala mansa e cheio de sorrisos, Vogeler marcava a divisão primeiro batendo com os dedos na tampa do piano, e depois cantarolava no mesmo ritmo frases improvisadas cujas sílabas indicava os tempos fortes da frase musical: [...]" (TINHORÃO, 1972, p. 150, 151).

Isto demonstra o diálogo existente entre a música e a dança, considerando o fato de que muitos artistas que compunham o elenco revisteiro eram polivalentes, ou seja, cantavam, dançavam, interpretavam, com um vocabulário expressivo e amplo, numa integração de linguagens artísticas.

No Teatro de Revista projetou-se, entre inúmeros outros, Francisco Alves. Ele, como era bastante comum na época, foi um artista que saiu dos picadeiros, representando desde personagens-tipo como o malandro até dançando ritmos da moda. Participou nos números de bailado, sendo exímio bailarino de maxixe, intérprete e cantor da música popular, como também de sambas. Francisco Alves teve sua carreira coroada como cantor de rádio e foi considerado o Rei da Voz. Participou de várias revistas (TINHORÃO, 1972).

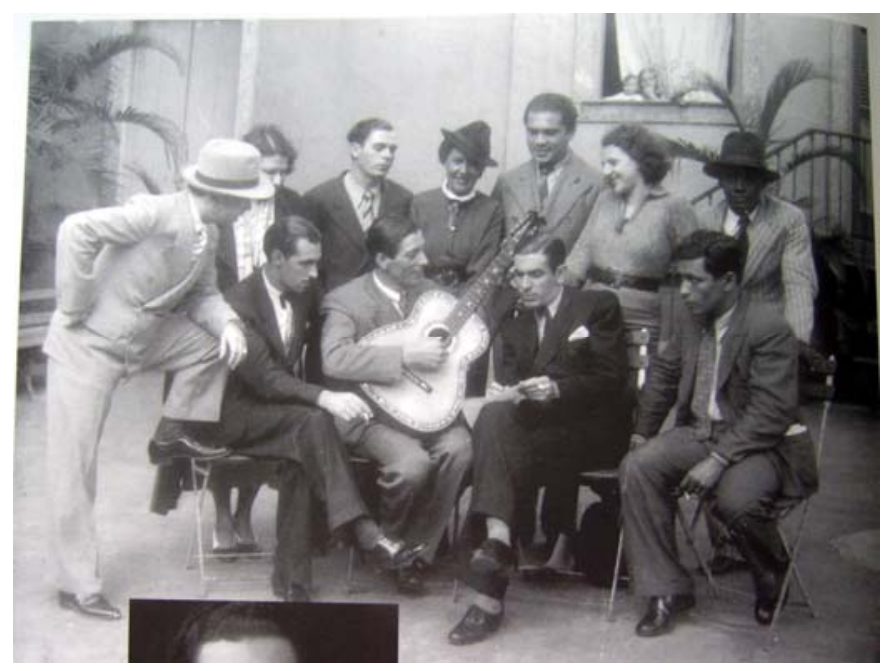

Imagem 4 - O cantor Francisco Alves com o seu inseparável violão, nos jardins do Teatro Recreio. CEDOC-FUNARTE. ${ }^{8}$

A partir da década de 1920, as músicas tornaram-se extremamente relevantes nesta dramaturgia e ocupavam o mesmo patamar que o texto declamado. Os números musicais destacavam-se de maneira ascendente.

\footnotetext{
${ }^{8}$ Fonte da foto obtida na obra de Delson Antunes: Fora de Série. Um Panorama do Teatro de Revista no Brasil. R.J.: FUNARTE, 2002, p.276.

CASCAES, Laura Silvana Ribeiro. A música e a dança no teatro de revista carioca. Música Popular em Revista, Campinas, ano 1, v. 2, p. 86-103, jan.-jun. 2013.
} 
Nesse período, intensificou-se o resgate de aspectos culturais brasileiros. Através das revistas carnavalescas, abriu-se um espaço privilegiado para o samba e para os sambistas, numa época em que ser oficialmente sambista era sinônimo de malandragem, de ser um sujeito fora da lei, que sofria perseguição policial. Só na década de 1930, o Carnaval foi oficializado, entretanto, nos anos 20, a linguagem do sambista e do carnaval tiveram trânsito livre e intenso junto ao Teatro de Revista.

\section{Conselho de "preto velho"}

O ritmo do samba e do carnaval passaram a se destacar junto às denominadas Revistas Carnavalescas. Dessa forma, as marchinhas e o Rei Momo se popularizaram. Veneziano (1996) comenta que a revista criou, então, outra feição e distanciou-se do modelo luso-francês.

Dessa forma, as Revistas Carnavalescas foram importantes para firmar a linguagem revisteira brasileira, retratando também alternativas de descolonização da música e da dança nesse gênero de teatro musicado. Concretizava-se, assim, o "samba", uma dança intensamente imbricada com a projeção do imaginário da modernidade, amalgamando em torno de si especulações acerca de uma matriz expressiva constituinte da identidade nacional.

A estrutura da dramaturgia das revistas carnavalescas contava com um rei momo e espelhava uma capital federal carnavalizada. Em geral, o momo, entusiasmado pelos ritmos carnavalescos, esmerava-se em resolver os males da cidade, caindo na folia.

A ação de cair na folia reacende a imagem projetada, de forma deliberada pelas revistas carnavalescas, que aproximavam a "alma carioca" como capaz de "vencer todas as dificuldades com bom humor, fato que se tornaria patente durante o que na época era conhecido como tríduo do momo" (GOMES, 2004, p.194).

O ritmo base das revistas carnavalescas eram a multiplicidade de tipos de samba e reforçavam uma dança repleta de volteios e requebros com os quadris e marcações de batidas com os pés. A apropriação do maxixe na década anterior antecipou e pro- 
jetou esta nova dança que vai ser sua grande sucessora. Foram se estreitando os laços com a música popular brasileira, bem como com as marchinhas de Carnaval.

Entre outras revistas carnavalescas e pré-carnavalescas, um grande sucesso da década de 1920 foi Olelê Olalá, escrita por Carlos Bitencourt e Cardoso de Menezes e música de Bento Mossurunga, em 1922 - uma peça que tinha o repertório repleto de fados, maxixes e sambas (PAIVA,1991).

Os números carnavalescos no Teatro de Revista apostavam na popularidade das sociedades carnavalescas que eram representadas no palco e que motivavam o público às torcidas que já não estavam vinculadas estritamente às vedetes, mas aos três clubes carnavalescos cariocas: os Fenianos (gatos), Os Tenentes do Diabo (baeta) e os Democratas (carapicus).

Assim sendo, o Teatro de Revista foi lançador de sucessos carnavalescos expressivos no palco, popularizado para as massas. Segundo Gomes,

essa relação do teatro de revista com a música popular era estreita a ponto de o jornal A Noite noticiar, a 09 de dezembro [de] 1925, que o Teatro São José organizaria um festival em meio a apresentação da revista Se a Moda Pega para eleger o melhor autor de sambas do ano. (GOMES, 2004, p.113)

As apropriações dos movimentos de dança do samba nos bailados do Teatro de Revista dialogaram com a tipificação dos personagens. Os tipos brasileiros que apareciam em cena motivavam ainda mais a atmosfera nacionalista que se impunha progressivamente na década de 1920.

Isto significava que as apropriações culturais foram elementos agregadores do sentido de brasilidade, e, nesse sentido, o repertório cultural do samba abriu alas para os personagens-tipo da mulata - da baiana - e do malandro, bem como para a tipificação de outros personagens. O personagem do malandro, de acordo com Veneziano (1991) conseguia “desrespeitar as duas maiores instituições do capitalismo, o trabalho e a família [...]" (1991,p.124).

Segundo Veneziano (op. cit), a tipificação da mulata condensava atributos tais quais: a sensualidade da mulher brasileira e o linguajar próprio. Esta personagem também se destacava dançando maxixes e sambas (VENEZIANO, op. cit.). As danças demarcavam um repertório de movimentos de matrizes afro-brasileiras, através do requebrado, reboleios de quadril ondulante, marcações e batidas com os pés ágeis. 
Dentro do espectro da linguagem musical do samba, o personagem-tipo do malandro embalava-se com o ritmo, acompanhando o sucesso das demais tipificações dos personagens. O gênero revisteiro, nessa época, difundiu as canções e os bailados, aproveitando a onda nacionalista na produção cultural para as massas. E o povo cantou e dançou a música e as danças populares brasileiras.

\section{Referências bibliográficas}

ANTUNES, Delson. Fora de Série. Um Panorama do Teatro de Revista no Brasil. Rio de Janeiro: FUNARTE, 2002.

O Homem do Tro-Lo-Ló: Jardel Jércules e o Teatro de Revista Brasileiro. Dissertação de Mestrado, UNIRIO, 1996.

AZEVEDO, Artur. Cocota. In: Teatro de Artur Azevedo. Tomo II. Rio de Janeiro: INACEN, 1985.

INACEN,1985.

. O Mandarim. In: Teatro de Artur Azevedo. Tomo II. Rio de Janeiro:

BEVILAQUA, Ana. Apoteoses Corporais: A Presença do Corpo na Cena Revisteira da Década de 20. Dissertação de Mestrado. UNIRIO, 2001.

CALDEIRA, Solange. A Presença da Dança nos Palcos Cariocas. In: Cadernos de Pesquisa em Teatro. Programa de Pós- Graduação em Teatro da UNIRIO. Série Ensaios. Rio de Janeiro, n. 5, 1999

EFEGÊ, Jota. Maxixe - A dança excomungada. Rio de Janeiro: Conquista, 1974.

GOMES, Tiago de Melo. Um Espelho no Palco: identidades sociais e massificação da cultura no teatro de revista dos anos 1920. Campinas: Unicamp, 2004.

HERSCHMANN, Michael e PEREIRA, Carlos. A Invenção do Brasil Moderno: medicina, educação e engenharia. Rio de Janeiro: Rocco, 1994.

MENCARELLI, Fernando. Cena Aberta - A absolvição de um bilontra e o teatro de revista de Arthur Azevedo. São Paulo: Editora da UNICAMP, 1999.

Nosso Século. Memória fotográfica do Brasil no século 20. Volume 2. 1910/1930. São Paulo: Abril Cultural,1981. 
PAIVA, Salvyano Cavalcanti de. Viva o Rebolado: Vida e Morte do Teatro de Revista no Brasil. Rio de Janeiro: Nova Fronteira, 1991.

PEREIRA, Roberto. A Formação do Balé Brasileiro: nacionalismo e estilização. Rio de Janeiro: FGV, 2003.

PESAVENTO, Sandra Jatahi. História \& História Cultural. Belo Horizonte: Autêntica, 2003.

RUIZ, Roberto. Araci Cortes Linda Flor. Rio de Janeiro: Funarte, 1984.

O Teatro de Revista no Brasil: do início a I Guerra Mundial. Rio de Janeiro: INACEN, 1988.

SALIBA, Elias Thomé. Raízes do Riso - A representação humorística na história brasileira: da Belle Epoque aos primeiros tempos do rádio. São Paulo: Companhia das Letras, 2002.

SEVCENKO, Nicolau. Literatura como Missão - Tensões Sociais e Criação Cultural na Primeira República. São Paulo: Companhia das Letras, 2003.

TINHORÃO, José Ramos. Música Popular Teatro \& Cinema. Petrópolis: Vozes, 1972.

VELLOSO, Monica Pimenta. América dançarina, polêmicas em torno de uma identidade nacional brasileira. In: Z Ensaios - Ano IV - Número 2 - Abril 2008/Julho 2008. Disponível em: http:/ / www.pacc.ufrj.br/z/ano4/2/mvelloso.htm. Acesso: 10 abr. 2009.

. Falas da cidade: conflitos e negociações em torno da identidade cultural no Rio de Janeiro. In: ArtCultura, v. 7, n. 11, 2005.

VENEZIANO, Neyde. O Teatro de Revista no Brasil: Dramaturgia e Convenções. Campinas: Pontes: UNICAMP, 1991.

Não Adianta Chorar: Teatro de Revista Brasileiro... Oba! Campinas: UNICAMP, 1996.

\section{Lista das peças (CEDOC - FUNARTE)}

Gato, Baeta e Carapicu, de Cardoso de Menezes. (1912)

Comidas, Meu Santo, de Marques Porto e Ary Pavão (1925).

Guerra ao Mosquito, de Marques Porto e Luiz Peixoto (1929). 